\title{
Management of children and young people with headache
}

\author{
William P Whitehouse, ${ }^{1,2}$ Shakti Agrawal ${ }^{3}$
}

\begin{abstract}
'Department of Paediatric Neurology, Nottingham Children's Hospital, Nottingham University Hospitals NHS Trust, Nottingham, UK ${ }^{2} 5$ chool of Medicine, University of Nottingham, Nottingham, UK ${ }^{3}$ Department of Paediatric Neurology, Birmingham Children's Hospital, Birmingham, UK
\end{abstract}

\section{Correspondence to} Dr William P Whitehouse, Division of Academic Child Health, School of Medicine, E Floor East Block, Queen's Medical Centre, Nottingham NG7 2UH, UK;

william.whitehouse@ nottingham.ac.uk

Received 10 August 2016 Revised 30 October 2016 Accepted 2 November 2016 Published Online First

20 December 2016

\section{CrossMark}

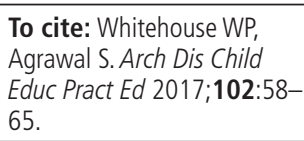

\begin{abstract}
Headache is very common in children and young people. The correct advice and treatment requires consideration of a wide differential diagnosis between primary and secondary headaches, and also of the different types of primary headache. The International

Classification of Headache Disorders gives useful descriptions and diagnostic criteria that are especially useful for primary headaches. The National Institute for Health and Care Excellence (NICE) Clinical Guideline 150 provides evidencebased recommendations on treatments for adults and young people from age 12 years. However, the same principles can be applied to younger children when a specific diagnosis can be made. Key recommendations from the NICE Quality Standards include, establishing a precise diagnosis if possible, avoiding, diagnosing and treating medication overuse headache, and combining a triptan with a non-steroidal antiinflammatory drug or paracetamol as the firstline acute/rescue treatment for migraine with or without aura. Although rare in children and young people, it is important to diagnose new daily persistent headache, as it responds poorly or not at all to medication; and paroxysmal hemicrania as it responds very well to indomethacin but not to other commonly used analgesics. When faced with difficulties in reaching a precise diagnosis or in finding effective therapies, further advice should be sought from a children's headache clinic or specialist.
\end{abstract}

\section{INTRODUCTION}

Although this article will focus on the drug therapy of primary headaches, it is vital that prescribers understand how to differentiate primary from secondary headaches and also the varieties of primary headache that will present in childhood. Diagnosis and therapeutic decisions are often complicated by comorbidities, and different primary headaches can coexist. So the more you know and understand about general paediatrics and paediatric headache disorders in particular, the better the advice you will give and the better will be the treatment options you can offer your patients.

Headache can be thought of as pain referred to the forehead, orbits, temples or scalp, and does not usually cover pain isolated to the face or neck. Pain is a complicated, all be it real, experience that demands and deserves medical attention. The International Association for the Study of Pain defined it as "an unpleasant sensory and emotional experience associated with actual or potential tissue damage, or described in terms of such damage". ${ }^{1}$ Therefore, pain can be caused by actual or incipient tissue injury, a disorder of the pain pathways or an illness behaviour, and in all cases is a powerful interpersonal communication. It is not surprising then, that some drugs that are very effective for pain associated with tissue injury, for example, opiates and anti-inflammatory drugs, are often only partially effective in other situations. Psychological support and interventions can make important contributions to restoring function in patients with pain generally and especially in migraine. Acknowledging the condition, allaying fear and addressing worries will help ease the suffering.

Recent reviews of headache in childhood, ${ }^{2}{ }^{3}$ and in preschool children, ${ }^{4}$ provide excellent summaries of the topic, and more comprehensive knowledge can be gleaned from "Childhood Headache 2nd Edition", and the Childhood Headache Training courses run in the UK by the British Paediatric Neurology Association. ${ }^{6}$ The National Institute for Health and Care Excellence (NICE) evidence-based guideline on headache in young people and adults is an accessible, succinct and invaluable resource, which covers the diagnosis and management of 
primary headaches in children and young people aged 12 years and above. ${ }^{7}$ It is currently being reviewed and updated. Formal diagnostic criteria for primary and secondary headaches have been revised and published in the International Classification of Headache Disorders 3rd edition. ${ }^{8}$

\section{TREATMENT DECISIONS}

After a careful clinical assessment, including a full history and tailored examination, decide on the most likely diagnosis and the important differentials. This will usually require no further investigations, and will allow you to give the child and their family reassurance and sensible advice. Occasionally, and especially when faced with an unclassified headache, for example, a non-specific chronic daily headache with no features to further define the diagnosis, investigations for symptomatic headache will be indicated. ${ }^{9}$ Box 1 summarises the key 'red flags', warning symptoms and signs, suggestive of a secondary headache, as does the HeadSmart campaign. ${ }^{10}$

\section{ADVISING NO MEDICATION}

The most important consideration is that, very often, it is best to recommend no medication. A mild headache (see box 2$)^{8}$ may cause concern even when the pain is slight and not interfering with function and participation. In this situation, clinical assessment, diagnosis, explanation and reassurance will usually address the concerns.

Often the child or young person will already have found out that simple analgesics (paracetamol or ibuprofen) have not helped and will be, quite rightly, unwilling to use them. Primary stabbing headache ${ }^{8}$ is an intense focal head pain lasting 1-3 s and occurring unpredictably without any trigger or autonomic symptoms or signs. It often occurs in people with migraine without aura, at a site within their usual migraine site, typically frontally. It is too short lived and

\section{Box 1 'Red flags'}

- Change in personality, behaviour, worsening school work or lethargy

- First severe headache

- Unclassified headache

- Accelerated course

- Change in headache (people with migraine can develop brain tumours, albeit rarely)

- Mainly when lying down or asleep or bending down, straining or coughing

- Abnormal growth or puberty

- New neurological signs: ataxia, cranial nerve deficit, head-tilt, papilloedema, visual impairment

- Convulsions/epileptic seizures

\section{Box 2 Headache intensity (severity) ${ }^{8}$}

\section{0 : No headache}

1: Mild headache: does not interfere with

usual activities, for example, carries on with work or play 2: Moderate headache: inhibits but

does not wholly prevent usual activities, for example, stops playing and just watches a film

3: Severe headache: prevents all purposeful activities, for example, just lies down quietly or sleeps

\section{Box 3 Medication overuse headache ${ }^{8}$}

Consider the possibility of medication overuse headache $(\mathrm{MOH})$ in patients developing a chronic headache, that is, on $\geq 15$ days a month, for $\geq 3$ months, who had previously episodic tension-type headache, migraine without aura or migraine with aura while taking the following, alone or in combination:

- triptans, ergot alkaloids, opiates or combination analgesics on $\geq 10$ days a month

- paracetamol, aspirin or any non-steroidal antiinflammatory drug on $\geq 15$ days a month

$\mathrm{MOH}$ typically presents when a bad patch of migraine with or without aura has transformed into a chronic daily headache, including chronic migraine.

Withdraw the suspect medication abruptly, and give advice on alternative treatments including in some cases prophylactic medication.

Complete remission after withdrawal is no longer a diagnostic criterion.

unpredictable to treat, but diagnosis and explanation do help. If frequent, indomethacin, as for paroxysmal hemicrania (see section 'paroxysmal hemicranias' within the section 'trigeminal autonimic cephalalgias'), is worth considering. New daily persistent headache ${ }^{8}$ is usually refractory to medication. However, in general it is worth checking the doses used in case a sufficiently high dose has not been tried. In patients with primary headache, however, be sure to advise them about medication overuse headache $(\mathrm{MOH}$, see box 3). ${ }^{8}$ Use the doses in your recommended reference source, for example, in the UK the British National Formulary for Children (BNF C) ${ }^{11}$ unless otherwise stated.

\section{PREVENTING MEDICATION OVERUSE HEADACHE}

$\mathrm{MOH}$ is common, especially in people with primary headaches, for example, migraine without aura or episodic tension-type headache, ${ }^{8}$ which becomes transformed by frequent use of any single analgesic into a chronic daily headache, less intense but just as 


\section{Box 4 Lifestyle advice}

\section{Encourage}

- As full participation in work and play activities as possible, between incapacitating headaches

- Regular and sufficient sleep

- Regular rest and relaxation

- Regular meals (particularly breakfast)

- Adequate hydration (drinking enough non-caffeinated fluids)

- Regular exercise, between incapacitating headaches

- Their understanding of primary headache, when applicable

\section{Discourage}

- Prohibitions on normal activities, foods or drinks, unless there is very clear evidence that one has been harmful in a particular case upsetting as the original primary headache. It can be explained as a 'rebound' headache, in people where the pathology is in the pain pathways rather than due to tissue damage. All patients with a primary headache should be warned about this and prescriptions for analgesics should state as well as the dose and maximum dose that can be taken in 24 hours, not to use them on more than 2 (or occasionally 3 ) days a week.

\section{NON-DRUG TREATMENTS AND ADVICE}

A variety of physical, complementary and lifestyle interventions are available, mostly with little empirical evidence of efficacy. However, acupuncture is included in the NICE guideline for chronic tensiontype headache and as a second-line treatment for migraine prophylaxis. ${ }^{7}$ Low-risk common sense advice has also traditionally been recommended

Table 1 Simple analgesics for the acute/rescue treatment of migraine with and without aura

Beware: Patients are susceptible to medication overuse headache, so use full doses but usually on no more than 2 days/week

\begin{tabular}{|c|c|c|c|}
\hline Age & Route & Dose & Preparation (pack) \\
\hline
\end{tabular}

1. Paracetamol

0-11 years Oral $\quad 20 \mathrm{mg} / \mathrm{kg} 4-6 \mathrm{hrly}$, max $75 \mathrm{mg} / \mathrm{kg} / \mathrm{day}$

Per rectum $\quad 40 \mathrm{mg} / \mathrm{kg}$, then $20 \mathrm{mg} / \mathrm{kg} \mathrm{4-6}$ hrly, $\max 75 \mathrm{mg} / \mathrm{kg} / \mathrm{day}$

10-50 kg Intravenous

$15 \mathrm{mg} / \mathrm{kg}$ 4-6 hrly (max $60 \mathrm{mg} / \mathrm{kg} /$ day)

$>50 \mathrm{~kg}$

12-18 years Oral

PR/intravenous

$1 \mathrm{~g}$ 4-6 hrly (max $4 \mathrm{~g}$ daily)

0.5-1 g 4-6 hrly, max 4 g/day

doses as above

2. Ibuprofen (NSAID)

2-6 years Oral

7-11 years

12-18 years

3. Diclofenac (NSAID)

1-18 years Oral/PR

2-18 years Intravenous/ intramuscular

$100 \mathrm{mg}$ three times a day, max $30 \mathrm{mg} / \mathrm{kg} /$ day

$200 \mathrm{mg}$ three times a day, max

$30 \mathrm{mg} / \mathrm{kg} /$ day, max $2.4 \mathrm{~g} /$ day

$400 \mathrm{mg}$ three times a day, max $600 \mathrm{mg}$ four times a day

$0.3-1 \mathrm{mg} / \mathrm{kg}$ three times a day, max $150 \mathrm{mg} /$ day

$0.3-1 \mathrm{mg} / \mathrm{kg}$ twice daily max $150 \mathrm{mg} / \mathrm{day}$

4. Ketorolac (NSAID)

1-15 years Intravenous (slow) $\quad 0.5-1 \mathrm{mg} / \mathrm{kg}(\max 15 \mathrm{mg}$ ) stat then $0.5 \mathrm{mg} / \mathrm{kg}(\mathrm{max} 15 \mathrm{mg})$

6 hrly, max $60 \mathrm{mg} /$ day for $48 \mathrm{~h}$

16-18 years

$10 \mathrm{mg}$ stat then $10-30 \mathrm{mg} 4$ hrly max 90 mg daily for 48 hours
Tabs: 200, 400, $600 \mathrm{mg}$;

Oral suspension: $100 \mathrm{mg} / 5 \mathrm{~mL}$; Orodispersible melts: $200 \mathrm{mg}$
Tabs: $500 \mathrm{mg}$; dispersible tabs 120, $500 \mathrm{mg}$;

Oral suspension: $120 \mathrm{mg} / 5 \mathrm{~mL}$, $250 \mathrm{mg} / 5 \mathrm{~mL}$

Suppositories: 60, 125, 250,

$500 \mathrm{mg}$

Intravenous infusion: $10 \mathrm{mg} / \mathrm{mL}$
Hepatic impairment

Renal impairment

Gastro pain, bleeding, ulceration, allergic reactions

Gastro pain, bleeding, ulceration,

Tabs: 25, $50 \mathrm{mg}$; Dispersible tabs: 10, $50 \mathrm{mg}$ Suppositories: $100 \mathrm{mg}$

Injection: $25 \mathrm{mg} / \mathrm{mL}$

Injection: $30 \mathrm{mg} / \mathrm{mL}$
Gastro pain, nasty taste, flushing, confusion

Some of the drugs/doses below are those suggested/used by the authors and may be outside the marketing authorisation. Always check usual reference sources/guidelines when using unfamiliar medicines. ${ }^{11}$

Hrly, hourly; max, maximum; NSAID, non-steroidal anti-inflammatory drug; tabs, tablets. 
including healthy lifestyle habits (see box 4). We routinely encourage the use of distraction (especially for mild and moderate headaches), cold or warm compresses and balms applied to the forehead and/or temples, for example, 'Tiger Balm White', '4-Head', etc. Excess caffeine, aspartame, monosodium glutamate, nitrites, alcohol and chocolate can cause headache (and vomiting); however, the role of exclusion diets per se in childhood migraine is still unproven.

\section{GENERAL ACUTE/RESCUE TREATMENTS}

Simple 'over-the-counter' analgesics, paracetamol and/ or ibuprofen are first-line treatments for symptomatic and most primary headaches, especially episodic tension-type headaches. ${ }^{7}$ Opiate analgesia should be offered for severe symptomatic headaches where there is known tissue damage, for example, for postoperative pain, but is not recommended for primary headaches. It seems less effective and more prone to dose escalation and dependency in patients with primary headaches, with associated incapacitating sedation, constipation, nausea and itching. See tables 1-3 for most useful medicines for migraine with or without aura.

Give the child or young person a headache diary to use. $^{12}$ This will help establish their headache diagnoses and whether the current acute/rescue and prophylactic treatments are working.

\section{MIGRAINE WITH OR WITHOUT AURA}

Triptans are a class of serotonin (5-hydroxytryptamine) $1 \mathrm{~B} / 1 \mathrm{D} / 1 \mathrm{~F}$ receptor agonists, which exert a particular antimigraine attack effect, probably at the level of the trigeminovascular system and its connections. ${ }^{5}$ Offer a triptan taken together with ibuprofen or paracetamol (or both) for attacks of migraine with or without aura. ${ }^{7}$ These combinations are more effective and cost-effective than using either in isolation. ${ }^{7}$ A nasal triptan, for example, sumatriptan or zolmitriptan will have a more rapid onset of action than oral or orodispersible formulations. The triptan can be repeated after 2 hours if required, but give the patient and parent/carer clear instructions on the maximum dose, for example, "two doses in 24 hours and on no more than two days a week". A nasal triptan may not be tolerated because of the 'taste' or, very rarely, it can produce an unpleasant 'feeling' or 'dizziness'. If this happens, it is worth trying an alternative triptan or formulation. If tolerated, a triptan should be tried for three different attacks before giving up for lack of efficacy. Three different triptans should be tried before accepting that this class of medicine is ineffective for a particular patient.

Although sumatriptan and zolmitriptan are the only triptans currently in the BNF $\mathrm{C},{ }^{11}$ and only sumatriptan has marketing authorisation (a 'licence') for young people aged 12-18 years, there are no particular contraindications to triptan use in this population or younger children, for example, of primary school age. We will occasionally use triptans, in the smaller doses available, in younger children 'off-label', in accordance with the UK Royal College of Paediatrics and Child Health advice to use the best treatment available irrespective of pharmaceutical company marketing strategies, especially when no 'licensed' product of that class is available. ${ }^{13}$

Table 2 Antiemetics for the acute/rescue treatment of migraine with and without aura

\begin{tabular}{|c|c|c|c|c|}
\hline \multicolumn{5}{|l|}{ 5. Cyclizine } \\
\hline $2-5$ years & $\begin{array}{l}\text { Oral } \\
\text { Per rectum } \\
\text { Intravenous }\end{array}$ & $\begin{array}{l}0.5-1 \mathrm{mg} / \mathrm{kg} \text { three times a day, } \\
\max 3 \mathrm{mg} / \mathrm{kg} / \text { day, max single dose } \\
25 \mathrm{mg}\end{array}$ & \multirow[t]{4}{*}{$\begin{array}{l}\text { Tabs: } 50 \text { mg; } \\
\text { Suppository: } 12.5,25,50,100 \mathrm{mg} \\
\text { Injection: } 50 \mathrm{mg} / \mathrm{mL}\end{array}$} & \multirow[t]{3}{*}{ Drowsiness, dystonia is rare } \\
\hline $6-11$ years & & $25 \mathrm{mg}$ up to three times a day & & \\
\hline $12-18$ years & & $50 \mathrm{mg}$ up to three times a day & & \\
\hline \multicolumn{4}{|c|}{ 6. Domperidone } & \\
\hline $\begin{array}{l}2-18 \text { years } \\
\leq 35 \mathrm{~kg} \\
>35 \mathrm{~kg}\end{array}$ & $\begin{array}{l}\text { Oral/ } \\
\text { Per rectum }\end{array}$ & $\begin{array}{l}250 \mu \mathrm{g} / \mathrm{kg} \text { three times a day, } \\
10 \mathrm{mg} \text { three times a day, }\end{array}$ & $\begin{array}{l}\text { Tabs: } 10 \mathrm{mg} \\
\text { Suspension: } 5 \mathrm{mg} / 5 \mathrm{~mL} \\
\text { Suppository: } 30 \mathrm{mg}\end{array}$ & $\begin{array}{l}\text { Avoid in hepatic impairment } \\
\text { Can prolong QT-interval, so caution in heart } \\
\text { disease, or with other drugs that can do the } \\
\text { same }\end{array}$ \\
\hline \multicolumn{5}{|c|}{ 7. Prochlorperazine } \\
\hline $5-11$ years & $\begin{array}{l}\text { Oral } \\
\text { Per rectum } \\
\text { Intramuscular }\end{array}$ & $\begin{array}{l}250 \mu \mathrm{g} / \mathrm{kg} \text { up to three times a day } \\
5 \mathrm{mg} \text { three times a day } \\
6.25 \mathrm{mg} \text {, max three times a day }\end{array}$ & \multirow{2}{*}{$\begin{array}{l}\text { Tabs: } 5 \mathrm{mg} \text {; syrup: } 5 \mathrm{mg} / 5 \mathrm{~mL} \\
\text { Suppository: } 5,25 \mathrm{mg} \\
\text { Buccal prep: } 3 \mathrm{mg} \text { tabs placed high } \\
\text { between upper lip and gum } \\
\text { Injection: } 12.5 \mathrm{mg} / \mathrm{mL}\end{array}$} & \multirow[t]{2}{*}{$\begin{array}{l}\text { Dystonia, akathisia, tardive dyskinesia, all } \\
\text { rare }\end{array}$} \\
\hline $12-18$ years & $\begin{array}{l}\text { Oral } \\
\text { Per rectum } \\
\text { Buccal } \\
\text { Intramuscular }\end{array}$ & $\begin{array}{l}5-10 \mathrm{mg} \text {, max three times a day } \\
12.5-25 \mathrm{mg} \text { three times a day } \\
1-2 \text { tabs twice daily } \\
12.5 \mathrm{mg} \text { up to three times a day }\end{array}$ & & \\
\hline
\end{tabular}

Some of the drugs/doses below are those suggested/used by the authors and may be outwith the marketing authorisation. Always check usual reference sources/guidelines when using unfamiliar medicines. ${ }^{11}$

Tabs, tablets. 
Beware: To avoid medication overuse headache, use on no more than 2 days/week

8. Sumatriptan

\begin{tabular}{|c|c|c|}
\hline $6-9$ years & Oral & $\begin{array}{l}25 \mathrm{mg} \text { at onset, repeat once after at least } \\
2 \text { hours if needed, } \max 2 \text { days/week }\end{array}$ \\
\hline \multirow[t]{3}{*}{$10-18$ years } & Oral & $\begin{array}{l}50-100 \mathrm{mg} \text { at onset, repeat once after at } \\
\text { least } 2 \text { hours, max } 2 \text { days/week }\end{array}$ \\
\hline & Subcutaneous & $\begin{array}{l}6 \text { mg at onset, repeat once after at least } \\
1 \text { hour, max } 2 \text { days/week }\end{array}$ \\
\hline & Intranasal & $\begin{array}{l}10-20 \mathrm{mg} \text { at onset, repeat once after at least } \\
2 \text { hours, max } 40 \mathrm{mg} / \text { day, max } 2 \text { days/week }\end{array}$ \\
\hline
\end{tabular}

Tabs: $50 \mathrm{mg}$

Injection: $6 \mathrm{mg} / 0.5 \mathrm{~mL}$

Nasal spray: $10 \mathrm{mg} / 0.1 \mathrm{~mL}$ actuation

( 2 and 6 unit dose sprays available)
Cardiac disease.

Tingling, tightness, flushing, dizziness, nasty taste (nasal spray)

9. Zolmitriptan

12-18 years Oral

Intranasal
$2.5-5 \mathrm{mg}$ at onset, repeat once after at least 2 hours, max $10 \mathrm{mg} /$ day, max 2 day/week $5 \mathrm{mg}$ at onset, repeat once after at least 2 hours, max $10 \mathrm{mg} /$ day, max 2 day/week
Tabs: $2.5 \mathrm{mg}$

Orodispersible: melts $2.5 \mathrm{mg}$

Nasal spray: $5 \mathrm{mg} / 0.1 \mathrm{~mL}$ actuation
Cardiac disease. Tingling, tightness, flushing, dizziness, nasty taste (nasal spray)

Other triptans include rizatriptan (halve the dose if on propranolol), almotriptan, eletriptan, frovatriptan, naratriptan, with less experience in children and young people

Used together with NSAID or paracetamol.

Some of the drugs/doses below are outwith the marketing authorisation. Always check usual reference sources/guidelines when using unfamiliar medicines. ${ }^{11}$

Max, maximum; NSAID, non-steroidal anti-inflammatory drug; tabs, tablets.

Many prescribers avoid triptans and similar vasoconstrictor drugs in hemiplegic migraine, a particular type of migraine with aura, ${ }^{8}$ even though a link to migrainous infarction or ischaemic arterial stroke has not been observed. ${ }^{14}$

There is no particular contraindication to oral contraceptive use by young people with migraine without aura; however, specialist advice should be sought for those with migraine with aura. ${ }^{7}$

Antiemetic medication is often needed early on in a migraine attack, together with specific treatment for the headache (as above), for example, cyclizine, domperidone, prochlorperazine. Metoclopramide is particularly associated with acute dystonic reactions including oculogyric crises, and is now only indicated as second-line treatment for postoperative or chemotherapy-related nausea and vomiting. We have therefore omitted metoclopramide and the paracetamol-metoclopramide combination (Paramax) from table 2 . However, if a patient has previously benefitted from metoclopramide without adverse effect, it should not be withheld. Another analgesic-antiemetic combination in frequent use (Migraleve) contains codeine, which is not generally recommended for primary headaches. There are a range of formulations for different routes of administration (see box 5).

Occasionally, vomiting and incapacitation are so severe in a migraine attack that the child or young person will need emergency department assessment and treatment with intravenous fluids for dehydration, and a parenteral triptan and a parenteral non-steroidal anti-inflammatory drug (NSAID) or paracetamol, and parenteral antiemetics.

\section{Box 5 Useful combinations}

For migraine with or without aura
Advise a triptan and a NSAID
Sumatriptan nasal spray and
Ibuprofen or
And with severe nausea and vomiting
Pacetamol; max 2 days a week
Consider a parenteral triptan and a parenteral NSAID
or rectal paracetamol or intravenous ketorolac or
intravenous paracetamol and a parenteral antiemetic
Sumatriptan nasal spray and
Diclofenac suppository and
Prochlorperazine buccal; max 2 days a week
- NSAID, non-steroidal anti-inflammatory drug.

\section{TREATING MEDICATION OVERUSE HEADACHE}

$\mathrm{MOH}$ (see box 3 for diagnostic criteria) is best treated by abrupt withdrawal of the likely causative analgesic or triptan. ${ }^{7}$ Warn the patient that headaches may get worse over a couple of weeks before the chronic daily headache improves. Physical treatments and lifestyle advice (see section on non-drug treatments and advice) can help, and sometimes migraine prophylaxis will be appropriate during and following withdrawal (see section prophylactic treatment for migraine).

\section{TRIGEMINAL AUTONOMIC CEPHALALGIAS}

Although comparatively rare in children, the trigeminal autonomic cephalalgias $(\mathrm{TACs})^{8}$ are important to 
recognise as they are very painful and incapacitating, and their pathology and treatment is different from migraine. However, effective first-line treatment is available, so if you are unfamiliar with them do consider referring to a paediatric or adult headache clinic, depending on the patient's age and local resources, for diagnostic and treatment advice.

Cluster headache, ${ }^{8}$ especially when lacking some of the typical features (ie, probable cluster headache), is seen more often in young people aged $12-18$ years than in younger children, and may be mistaken for an epilepsy, or psychogenic non-epileptic attacks, or other medically unexplained illness behaviour. ${ }^{15}$ High flow $(12 \mathrm{~L} / \mathrm{min}) 100 \%$ oxygen by a non-rebreathing face mask with a reservoir bag is usually very effective acutely. When indicated, home and ambulatory oxygen will need to be provided. ${ }^{7}$ Triptans, subcutaneously or nasally can also help. ${ }^{7}$

Table 4 Prophylactic treatments for primary headaches: migraine with or without aura, episodic tension-type headache, chronic migraine, chronic tension-type headache

Regular prophylactic treatments

1. Topiramate (antiepileptic)

2-18 years Oral $0.5 \mathrm{mg} / \mathrm{kg}$ slowly up to $10 \mathrm{mg} / \mathrm{kg} /$ day, $\max 10 \mathrm{mg} / \mathrm{kg} / \mathrm{day}$, max $200 \mathrm{mg} / \mathrm{day}$

Tabs: 25, 50, 100, $200 \mathrm{mg}$ Sprinkle caps: 15, 25, $50 \mathrm{mg}$

Caps: $100,300,400 \mathrm{mg}$ Tabs: $600,800 \mathrm{mg}$

$300 \mathrm{mg}$ three times a day, then up to $\max 1.2 \mathrm{~g}$ three times a day

4. Sodium valproate (antiepileptic) 1-18 years Oral 10 slowly up to $40 \mathrm{mg} / \mathrm{kg} /$ day, max $1.5 \mathrm{~g}$
twice daily

Tabs: 100, 200, $500 \mathrm{mg}$ Oral solution: $200 \mathrm{mg} / 5 \mathrm{~mL}$

5. Flunarizine (calcium channel blocker, in the UK only on a named-patient basis) ${ }^{5} 1718$

\begin{tabular}{|c|c|c|c|}
\hline $\begin{array}{l}5-9 \text { years } \\
(20-40 \mathrm{~kg})\end{array}$ & Oral & $\begin{array}{l}0.1-0.3 \mathrm{mg} / \mathrm{kg} / \text { day, } 2.5-5 \mathrm{mg} \text { once daily, } \\
\text { max } 10 \mathrm{mg} \text { once daily }\end{array}$ & Tabs: 5, $10 \mathrm{mg}$ \\
\hline $\begin{array}{l}10-18 \text { years } \\
(>40 \mathrm{~kg})\end{array}$ & & $\begin{array}{l}10 \mathrm{mg} \text { once daily } \\
\max 20 \mathrm{mg}\end{array}$ & \\
\hline
\end{tabular}

6. Amitriptyline (tricyclic antidepressant)

$\begin{array}{ll}6-11 \text { years } & \text { Oral } \quad 10-20 \mathrm{mg} \text { at night } \\ 12-18 \text { years } & 25-50 \mathrm{mg} \text { at night }\end{array}$

Coated tabs: 10,25, $50 \mathrm{mg}$ Oral solution: $25 \mathrm{mg} / 5 \mathrm{~mL}$

\section{Riboflavin (vitamin $B_{2}$ )}

1-18 years Oral $\quad 50-100 \mathrm{mg}$ once daily-twice daily, max $400 \mathrm{mg} / \mathrm{day}$

8. Pizotifen (serotonin 5-HT2 antagonist)

$\begin{array}{lll}\text { 5-11 years } \quad \text { Oral } & 500 \mu \mathrm{g} \text { increasing to } 1 \mathrm{mg} \text { at night, } & \text { Tabs: } 500 \mu \mathrm{g}, 1.5 \mathrm{mg} \\ & \max 1.5 \mathrm{mg} / \text { day } & \text { Elixir: } 250 \mu \mathrm{g} / 5 \mathrm{~mL}\end{array}$

12-18 years $\quad 1.5 \mathrm{mg}$ increasing to $3 \mathrm{mg}$ at night, $\max 4.5 \mathrm{mg} / \mathrm{day}$
Bright yellow urine

Weight loss, paraesthesia, fatigue, drowsiness, impaired memory. There is a smaller risk of teratogenicity than with sodium valproate.

Avoid abrupt withdrawal

Avoid in asthma

Sleep problems

Avoid sudden withdrawal

Weight gain, tremor. Avoid in young females of 12 years and more because of teratogenicity, intellectual disability after fetal valproate exposure and irregular periods.

Give as evening dose Sedation, weight gain, tremor, irregular periods

Dry mouth, sedation, blurred vision, constipation

Beware risk of cardiovascular fatality in overdose

Drowsiness, increased appetite, weight gain, nausea, dizziness, anxiety, aggression

Some of the drugs/doses below are outwith the marketing authorisation. Always check usual reference sources/guidelines when using unfamiliar medicines. ${ }^{11}$

5-HT, 5-hydroxytryptamine; max, maximum; caps, capsules; tabs, tablets. 
Paroxysmal hemicranias ${ }^{8}$ is another TAC experienced rarely in children from preschool to secondary school ages, which is very effectively treated with indomethacin (combined with omeprazole, or ranitidine or similar). Response to indomethacin is so typical that it is formally a diagnostic criterion, ${ }^{8}$ so children with some but not all the typical features should be tried with indomethacin, for example, for 2-3 weeks.

\section{PROPHYLACTIC TREATMENT FOR MIGRAINE}

Because episodic tension-type headache, migraine without aura and migraine with aura are on a continuum, ${ }^{16}$ it is unusual to find someone with episodic tension-type headache requiring prophylactic treatment who does not also have migraine with or without aura. Similarly, chronic tension-type headaches ${ }^{8}$ would not usually require prophylactic treatment, but if it did the diagnosis should be reviewed, thinking of a symptomatic headache (eg, idiopathic intracranial hypertension, sinusitis, etc), or more likely chronic migraine. ${ }^{8}$

When incapacitating headaches, particularly migraine with or without aura, occur three or four times a month or more, depending on their severity and impact, offer a daily prophylactic medication. The choice will depend on preferences and comorbidities. Most drugs should be titrated up if starting low doses prove to be ineffective, and the drug should be reduced or abandoned if there are adverse effects or relatively high doses prove to be ineffective. Avoid combinations of prophylactic treatments, except during switching (see table 4).

Topiramate is effective for patients with chronic daily headache, for example, in adults with chronic migraine. ${ }^{19}$ It is also a first-line prophylactic treatment for migraine with or without aura in younger children, ${ }^{20}$ as well as in young people and adults. ${ }^{7}$ Although recommended doses are lower than those often used for epilepsies, these patients are at no more risk of adverse effects than children with epilepsies. The risk of teratogenicity in young women is significantly less than for sodium valproate.

Other drugs with reasonable evidence of efficacy in migraine in children and young people include propranolol and gabapentin. ${ }^{7}$ Some weaker evidence is also available for valproate, ${ }^{7}$ flunarizine, ${ }^{17}{ }^{18}$ amitriptyline $^{7}$ and riboflavin. ${ }^{7}$ Unfortunately, there is no good evidence for pizotifen's efficacy ${ }^{7}$ despite being a 'licensed' and popular treatment in the UK and it certainly seems to work well for some children and young people, in the authors' experience. Moreover, as it is now off-patent, it seems unlikely that a properly powered trial will ever be funded, unless a novel formulation is developed and patented.

\section{MENSTRUAL-RELATED MIGRAINE}

Some young women have predictable menstrualrelated migraine. ${ }^{8}$ If first-line acute/rescue treatments are ineffective and/or not tolerated, consider a triptan twice or three times a day, on the days migraine attacks are expected, even if that is a few consecutive days. Good evidence for this approach exists for zolmitriptan and frovatriptan. ${ }^{7}$

\section{PROPHYLACTIC TREATMENTS FOR TACS}

Cluster headache and probable cluster headache in children and young people are generally best diagnosed and treated in specialist paediatric or adult headache clinics. There is good evidence to support verapamil as a prophylactic. ${ }^{7}$

Paroxysmal hemicrania responds within a few days of reaching an effective dose of indomethacin. ${ }^{8}$ This is true for some cases not fulfilling all the diagnostic criteria, that is, probable paroxysmal hemicrania. Treatment should be combined with omeprazole or ranitidine or similar drug to reduce the risk of gastrointestinal adverse effects, particularly ulceration and

\section{Test your knowledge}

Select the best single answer:

1. Pain

A. is an unpleasant sensory experience caused by tissue injury

B. involves an emotional experience component as well as (A)

C. includes the description of (B) but with potential or actual tissue injury

D. includes the description of (B) even in the absence of potential/actual tissue injury

E. is not definable, but can reliably be recognised.

2. Medication overuse headache

A. can happen with primary and secondary headaches

B. can happen with prophylactic and acute/rescue analgesia

C. can happen when acute/rescue analgesia is used on more than 14 days a month

D. can happen when acute/rescue analgesia is used on more than 20 days a month

E. is best treated with gradual withdrawal of the offending medication.

3. A triptan with a NSAID

A. is the most effective treatment for attacks of migraine with or without aura

B. is recommended for new daily persistent headache and migraine without aura

C. is recommended for migraine with aura in young people 16 years of age or older

D. should not be used before trying at least one NSAID and one triptan on its own

E. should not be used together at the same time.

The answers are after the references 
bleeding. It can be continued for 2-3 weeks then stopped, but will need to be reinstated promptly when the paroxysmal hemicrania relapses. The paroxysmal hemicrania may settle in months or continue for years. Relatively low maintenance doses can often work. ${ }^{21}$ If indomethacin is not tolerated, further expert advice should be sought.

\section{CONCLUSIONS}

The management of children and young people with headache therefore depends on the correct diagnosis and differential diagnosis. This article for the Medicines Update has focussed on drug treatments. However, it is important to stress that drug treatment is not always needed, and certainly prophylactic treatment is not usually needed in migraine with or without aura, and almost never needed in tension-type headache. Acute/rescue treatments for severe and incapacitating primary headaches and for secondary headaches with tissue damage will be needed, but the correct choice depends on the precise diagnosis. Resources to help in the diagnosis and holistic management have been sign-posted.

Acknowledgements We are grateful to all our patients and their families, our students and teachers and especially to colleagues who have taught us so much about children's headaches: Dr Judith Hockaday, Dr Richard Newton, Dr Ishaq Abu-Arafeh, Dr Dilip Nathan, Dr Rachel Howels and colleagues on the NICE gc150 guideline development group.

Contributors WPW reviewed the literature, wrote most of the first draft and reviewed and edited the article following editor's and reviewer's suggestions, read and approved the final version. SA reviewed the literature, compiled the first draft of the tables and helped edit the article following the editor's and reviewer's comments, read and approved the final version.

Competing interests None declared.

Provenance and peer review Commissioned; externally peer reviewed.

\section{REFERENCES}

1 International Association for the Study of Pain (IASP) Subcommittee on Taxonomy. Pain terms: a list with definitions and notes on usage. Pain 1979;6:247-52.

2 Newton RW. Childhood headache. Arch Dis Child Edu Pract Ed 2008;93:105-11.

3 Abu-Arafeh I. Diagnosis and management of headache in children and adolescents. Prog Neurol Psychiatry 2014;18:16-20.

4 McCrea N, Howells R. Fifteen minute consultation: headache in children under 5 years of age. Arch Dis Child Edu Pract Ed 2013;98:181-5.

5 Abu-Arafeh I, ed. Childhood headache. 2nd edn. London: Mac Keith Press, 2013.
6 Children's Headache Training (CHaT). http://www.bpna.org. uk/headache/ (accessed 14 Feb 2015).

7 National Institute for Health and Care Excellence (NICE). Diagnosis and management of headaches in young people and adults. September 2012. https://www.nice.org.uk/guidance/ cg150 (accessed 14 Feb 2015).

8 Classification Committee of the International Headache Society. The international classification of headache disorders, 3rd edition (beta version). Cephalalgia 2013; 33:629-808.

9 Ahmed MAS, Martinez A, Cahill D, et al. When to image neurologically normal children with headaches: development of a decision rule. Acta Paediatr 2010;99:940-3.

10 HeadSmart. http://www.headsmart.org.uk/ (accessed 14 Feb 2015).

11 BNF and BNF C. https://www.medicinescomplete.com/about/ subscribe.htm (accessed 14 Feb 2015).

12 BPNA Headache Diary. http://www.bpna.org.uk/audit/ Headache\%20diary.PDF (accessed 14 Feb 2015).

13 Fox A, Sammons for the RCPCH. The use of unlicensed medicines or licensed medicines for unlicensed applications in paediatrics. December 2013. http://www.rcpch.ac.uk/system/ files/protected/page/The $\% 20$ use $\% 20$ of $\% 20$ unlicensed $\%$ 20medicines\%20or\%20licensed\%20medicines.pdf (accessed 14 Feb 2015).

14 Artto V, Nissilä M, Wessman M, et al. Treatment of hemiplegic migraine with triptans. Eur J Neurol 2007;14:1053-6.

15 McNabb S, Whitehouse W. Cluster headache-like disorder in childhood. Arch Dis Child 1999;81:511-12.

16 Viswanathan V, Bridges SJ, Whitehouse W, et al. Childhood headaches: discrete entities or continuum? Dev Med Child Neurol 1998;40:544-50.

17 Sorge F, De Simone R, Marano E, et al. Flunarazine in prophylaxis of childhood migraine. A double-blind, placebo-controlled, crossover study. Cephalalgia 1988;8:1-6.

18 Mohamed BP, Goadsby PJ, Prabhakar P. Safety and efficacy of flunarazine in childhood migraine: 11 years' experience, with emphasis on its effect in hemiplegic migraine. Dev Med Child Neurol 2012;54:274-7.

19 Silberstein S, Lipton R, Dodick D, et al. Topiramate treatment of chronic migraine: a randomized placebo-controlled trial of quality of life and other efficacy measures. Headache 2009;49:1153-62.

20 Buch ML. Use of topiramate in preventing pediatric migraine. Pediatr Pharmacother 2013;19:1-4.

21 Blankenburg M, Hechler T, Dubbel G, et al. Paroxysmal hemicrania in children-symptoms, diagnostic criteria, therapy and outcome. Cephalalgia 2009;29:873-82.

\section{Answers to the multiple choice questions}

1. D; 2. C; 3. A. 